\title{
Greenhouse Gas Emissions, Pine Bee- tles And Humans: The Ecologically Mediated Development Of British COLUMBIA's CARBON TAX
}

\author{
StePhanie Sodero
}

\begin{abstract}
In 2008, the province of British Columbia was an early mover in North America introducing a broad-based and escalating carbon tax. This article explores the interface between the human and non-human environment that resulted in this policy outcome. I use Actor-Network Theory, with its emphasis on the co-construction of human and non-humans, to describe, inform, and problematize the way humans relate to the non-human environment. Drawing on a post-humanist Latourian perspective, I examine the interlocking relationship between "chemical reactions and political reactions." I explore five examples of human and non-human mediation in the development of British Columbia's carbon tax: environmental pricing, the beetle epidemic, political economy, emissions accounting, and emotion. Applying Actor-Network Theory to the case of British Columbia's carbon tax disrupts traditional anthropocentric approaches to policy development, highlighting the role of the non-human environment in shaping, rather than simply being shaped by, policy.
\end{abstract}

Keywords: Actor-Network Theory, British Columbia, Carbon Taxation, Environment, Mediation, Post-Humanist

Résumé. En 2008, la province de Colombie britannique est précurseur en Amérique du Nord : elle introduit une taxe carbone croissante et globale. Cet article explore l'interface entre environnement humain et non-humain qui conduit à ce résultat politique. J'utilise la Théorie de l'Acteur-Réseau en insistant sur la co-construction des humains et non-humains pour décrire, informer et problématiser la manière dont les humains s'identifient à l'environnement non-humain. En mobilisant une perspective latourienne post-humaniste, j'examine la relation d'emboîtement entre " réactions chimiques et réactions politiques ». J'explore cinq exemples de médiation humaine et non-humaine dans le développement de la taxe carbone en Colombie britannique : fiscalité environnementale, l'épidémie des dendoctrones du pin, économie politique, comptabilisation des émissions, et émotion. Appliquer la Théorie de l'Acteur-Réseau au cas de la taxe carbone 
en Colombie britannique bouleverse les traditionnelles approches anthropocentriques de l'élaboration des politiques, en soulignant le rôle de l'environnement non-humain qui forme, plutôt que simplement formé par, les politiques.

Mots clés: Théorie de l'Acteur-Réseau, Colombie britannique, Taxation carbone, Environnement, Médiation, Post-humanisme

\section{INTRODUCTION}

In 2008, the province of British Columbia was an early mover in North America introducing a broad-based and escalating carbon tax. Given the cultural resistance to taxation in North America, the implementation of a carbon tax is notable (Hsu et al. 2008). This article explores the interface between the human and non-human environment that resulted in this policy outcome. I draw on Actor-Network Theory (ANT), with its post-humanist emphasis on the co-constructed nature of social life, to describe, inform and problematize the way humans relate to the non-human environment. Applying ANT to the case of British Columbia's carbon tax disrupts traditional anthropocentric approaches to policy development, highlighting the role of the non-human environment in shaping, rather than simply being shaped by, policy. In short, I explore the relationship between "chemical reactions and political reactions" (Latour 1993: 1).

A carbon tax assigns a price on greenhouse gas pollution, measured in carbon dioxide equivalents, that causes anthropogenic climate change. The goal of the environmental pricing mechanism is to decrease fossil fuel consumption by increasing the cost of burning fossil fuels. The tax, in theory, is designed to change the relationship between humans, fossil fuels and the atmosphere. Where an individual previously paid only for the gas to fill her tank, she now also pays for the pollution released into the atmosphere. In theory, a substantial taxation level complemented by mitigation measures such as efficient community design (e.g. compact, mixed use development), alternative transport modes (e.g. walking, cycling, transit, car share, trains), alternative fuels (e.g. biofuel, ethanol) and/or alternative vehicles (e.g. electric, hybrid) will result in a shift to a lower-carbon or post-carbon society.

First, I present an overview of British Columbia's carbon tax. Second, I discuss the social-ecological co-construction inherent in both carbon taxation policies and ANT. Third, I provide an overview of the development of British Columbia's carbon tax process. Fourth, drawing on semi-structured conversations, I explore five examples of human and non-human interaction in the development of British Columbia's carbon 
tax: environmental pricing, the pine beetle epidemic, political economy of place, greenhouse gas emissions accounting and emotion. Finally, I discuss how ANT contributes to a richer understanding of British Columbia's carbon tax specifically and a post-humanist understanding of the mediated character of the natural environment generally.

\section{British Columbia’s Carbon Tax}

British Columbia's carbon tax took effect July 1, 2008. The tax takes the form of a revenue neutral tax shift where the introduction of the carbon tax is matched with decreases in personal and corporate income taxes. The tax was initially set at the low level of 2.4 cents per litre ( $\$ 10$ per tonne of carbon emissions) to foster political palatability. The tax level escalated annually, reaching its highest scheduled price point of 7.2 cents per litre ( $\$ 30$ per tonne) in 2012 (Government of British Columbia 2008a). British Columbia's carbon tax is broad-based, applying to all sectors of the economy, and accounting for 77 per cent of the province's greenhouse gas emissions (Pembina 2012). Exemptions are in place for certain industrial practices, such as processing natural gas and cement (British Columbia Climate Action Team 2008). The design of British Columbia's carbon tax, including its escalating structure, revenue neutrality and broad emissions base is closely aligned with environmental economic theory (Pembina 2012; Social Prosperity 2012).

As of 2012, it is estimated that the carbon tax has reduced British Columbia's greenhouse gas emissions by three million tonnes annually (Government of British Columbia 2009a). As of 2010, British Columbia's emissions decreased by ten per cent, though it is difficult to determine what portion of this was caused by the carbon tax (Sustainable Prosperity 2012). It is estimated that British Columbia's tax generated $\$ 1.17$ billion in 2012/13, the sum of which will be redistributed to citizens and corporations via income tax reductions (Pembina 2012).

The carbon tax is a component of British Columbia's 2008 Climate Change Action Plan, which commits the province to decreasing greenhouse gas emissions 33 per cent by 2020, approximately 10 per cent below 1990 levels (Government of British Columbia 2008b). To this end, the government implemented a suite of initiatives. For example, the use of sustainable transport modes and energy efficient vehicles was addressed through a Green Communities Statue Amendment, a Public Transit Plan, a Vehicle Emissions Act and a Renewable and Low Carbon Fuel Act (Government of British Columbia 2008c; Government of Brit- 
ish Columbia 2007). The carbon tax was introduced as a back stop to complement such measures.

\section{Actor-Network Theory As Ecological}

The role of the non-human environment is integral to both ANT and carbon pricing policy. Carbon taxation is based on an understanding that humans can adversely affect the atmosphere, and in turn the climate, on which we depend. This understanding is predicated on recognition that humans are not separate from the ecosystem, but instead, are an interdependent component of a global ecosystem (Murdoch 2001). Humans are dependent on natural systems and ecological services that make our existence possible, such as atmospheric conditions resulting in a habitable climate and the hydrological cycle producing potable water (Hawken et al. 1999). This perspective lends weight to calls to dispel dichotomies, such as society/nature, that simplify the degree of interconnectedness between the human and non-human environment (Bennett 2010; Latour 1993; Murdoch 2001). Overcoming such false dichotomies may "enable an 'ethics of care,' or 'partnership,' between humans and nonhumans to emerge" (Bennett 2010; Murdoch 2001: 113).

Bennett extends this blurring of boundaries. She argues that even the human body is not "exclusively human": the crook of the elbow is "a special ecosystem, a bountiful home to no fewer than six tribes of bacteria" (2010: 112). The human body is not $a$ body, but an "array of bodies" (Bennett 2012: 112). Bennett argues for a vital materiality that recognizes the capacity of things, such as carbon dioxide molecules, pine beetles and wind, to have their own momentum and directionality that can easily thwart the intentions of humans.

Just as British Columbia's carbon tax aims to make the non-human environment visible, so does ANT. ANT is described as an "ecological theory" as it treats human and non-human nature, as well as other non-human entities, such as technology and texts, as equally enrolled in constituting the social (Murdoch 2001: 114). ANT theorists aim to disrupt the habitual dichotomy of society and nature in favour of examining actual, rather than predefined, relationships (Latour 2005; Law 1992).

Latour (1993) observes that human action is not conducted in isolation, but in coordination with extensive networks of people and things. The role of ANT, according to Murdoch, is to "identify how relations and entities come into being together" (2001: 111). This process of moving forward together, whether conscious or unconscious, results in a "reshaping" of humans and non-humans (Rutland and Aylett 2008: 627). 
For example, humans burn fossil fuels which release greenhouse gases that cause climate change. Climate change in turn impacts humans in terms of shifting ecosystems, storm events and sea level rise. Humans then, as in the case of British Columbia, attempt to modify their polluting behaviour. The earth is a closed ecosystem; actions "boomerang" back upon their origins (Beck 1992).

Humans do not exist in isolation but are enrolled in materialist assemblages, "imbroglios of people and things," that result in the co-construction of humans and non-humans (Latour 2011: 4). This is particularly the case with the natural environment on which humanity depends. "Nature, contrary to appearances," Latour argues, "is a political animal. It is what is used to define the world we have in common, the obvious existence we share, the sphere to which we all pertain equally; it is what connects us" (2011: 8).

Several contemporary researchers explore this common existence (see Fisher 2006; Folke et al. 2010; Freudenburg et al. 2008; Gramling and Freudenburg 2012; Latour 2011; MacKenzie 2009; Murphy 2009, 2004; Slocum 2004; Urry 2008; Youngmen 2009). Fisher argues for the acknowledgement of the "conjoint constitution of society and environment" in sociology (2006: 469), while Murphy draws on the metaphor of dance to describe the co-constructed relationship between humans and non-humans: "human agents dance with the moves of nature's actants to form hybrid constructions. Importantly, the dance can be adroitly or ineptly performed" (2004: 254).

In the Canadian context, Murphy's (2004) study of the 1998 ice storm that affected the provinces of New Brunswick, Nova Scotia, Ontario and Quebec, as well as the American states of Maine, New York, New Hampshire and Vermont, is an example of a crisis where the co-construction of the social and ecological was made visible. Murphy contrasts the devastating impact in mainstream society with the lack of impact in Amish communities in New York state, observing that the adroit performance of the Amish yields lessons for other communities. The Amish do not rely on electricity from the provision of heat, light, water or food production. Consequently, during the ice storm their lives continued largely without disruption, with the exception, perhaps, of providing more assistance than usual to their non-Amish neighbours. In contrast, a state of emergency was declared in mainstream society (Murphy 2004). Murphy concludes that "susceptibility to disaster was socially constructed, not natural" (2004: 257). The Amish's selective use of modern technology is an example of an attempt to harmonize social practices with nature's dynamics, as well as to ensure that technological practices do not disrupt social practices. The carbon tax is a market-based attempt to harmonize 
human activity with the earth's carrying capacity (Durning and Bauman 1998).

\section{The Development Of British Columbia’s Carbon Tax}

I use ANT to incrementally retrace how carbon taxation evolved from academic theory to political priority to practical reality. Based on conversations conducted in the field in fall 2009 with 24 politicians, civil servants, carbon tax advocates, and carbon tax opponents, six stages of the policy development process emerged each with a unique constellation of human and non-human actors: "Starting line, 1998-2000," "Hitting the wall, 2001-2006," "Changing course 180 , July 28, 2006 - February 13, 2007," "Hitting stride, February 14, 2007- May 28, 2008," "Stumbling over hurdles, June 2008 - May 12, 2009" and "Staying the course, May 13, 2009 - " (Table 1) ("Author" 2011). In this article I focus on the ecological emphasis of ANT in order to tease apart the co-construction of human and non-human nature in the policy development process. To this end a summary of the policy development process provides useful context (see also "Author" 2010; Duff 2008; Peet and Harrison 2012; Pembina 2012).

In the first phase, "Starting Line, 1998-2000," a booklet published by the non-governmental organization Northwest Environment Watch, was central to environmental pricing discussions in British Columbia. The document was read by and influenced the actions of the New Democratic Environment Minister Joan Sawicki, as well as the Leader of the Opposition Gordon Campbell. The New Democratic Party commissioned an academic study, Environmental Tax Shift: A Discussion Paper for British Columbians. This in turn informed the 2000 Budget which included a proposal for three tax shifting pilot projects.

In the second phase, "Hitting the wall, 2001-2006," Premier Gordon Campbell, leader of the more conservative Liberal Party, gained power. With his centralized political power he was able to pursue policies aligned with conventional taxation, rather than environmental tax shifting. The New Democrats' proposed tax shifting pilot projects were not implemented. As well, Campbell reduced the government's role in addressing climate change. However, during this phase of human inactivity on climate change, the activity of the pine beetle became physically, economically and politically visible.

The third phase, "Changing course $180^{\circ}$, July 28, 2006 - February 13,2007 ," marked a period of dramatic change. Within the span of six months, British Columbia went from approving its first coal-fired power 
plants to announcing ambitious climate change plans, including an oblique reference to carbon taxation in the 2007 Throne Speech. This reversal of position was influenced by the actions of the Republican Governor of California, Arnold Schwarzenegger, who in 2006 announced a Global Warming Solutions Act that received international recognition. The reputation of Premier Campbell was reinvented, swinging from antienvironment to pro-environment seemingly overnight.

In the fourth phase "Hitting stride, February 14, 2007-May 28, 2008," the government of British Columbia, specifically the Premier, the Cabinet Committee on Climate Action, the Climate Action Secretariat and the Ministry of Finance coalesced around climate action. This was largely a closed process that focused on policy design. In the case of carbon taxation, ensuring the tax was revenue neutral, rather than revenue generating, was a priority for the conservative Liberal Party.

In the fifth phase, "Stumbling over hurdles, June 2008-July 2008," the government's lack of communication strategy left it unprepared to respond to public and political opposition. On July 1, 2008, the carbon tax went into effect, coinciding with a spike in market price fluctuations, leading to vocal opposition to the carbon tax. This opposition receded as gas prices declined over the following months. In 2009, the carbon tax was the focus of the New Democratic Party's "Axe the Tax" campaign leading up to a May election. This tactic was surprising and alienating for party supporters as the New Democrats historically aligned themselves with the environmental community, and just a decade earlier pursued environmental tax shifting measures. The Liberal Party was re-elected and the carbon tax increased, as scheduled, on July 1, 2009. In the sixth and ongoing phase, "Staying the Course, 2009-," a range of actors, including government, non-governmental organizations, academics, business associations, public transit service providers and the public are monitoring the environmental effectiveness, revenue generation and public acceptability of the carbon tax.

\section{Ecological Mediation}

I use ANT to shed light on the role that the non-human environment played in the development of British Columbia's carbon tax. ANT highlights the ways in which the human and non-human environment actively co-construct each other, an approach that is particularly relevant to the issue of climate change where the atmospheric effects of greenhouse gas emissions boomerang on human populations (Beck 1992). Focusing on five areas: environmental pricing, the pine beetle epidemic, political 
economy of place, greenhouse gas accounting and emotion, I explore how the non-human environment is made visible in the policy development process. I anchor this discussion by loosely aligning each of the five areas with phases of the policy development process, though in reality they are highly integrated (Table 1).

Table 1: Outline of six phases of British Columbia's carbon tax development aligned with five areas of social-ecological mediation

\begin{tabular}{|c|c|c|c|c|}
\hline \# & Date & Phase & $\begin{array}{l}\text { Social-ecological } \\
\text { mediation }\end{array}$ & $\begin{array}{l}\text { Characteristic of } \\
\text { the social- } \\
\text { ecological } \\
\text { relationship }\end{array}$ \\
\hline 1 & $1998-2000$ & Starting line & Economy & $\begin{array}{l}\text { Empowerment/con } \\
\text { trol }\end{array}$ \\
\hline 2 & $2001-2006$ & Hitting the wall & Ecology & $\begin{array}{l}\text { Urgency/lack of } \\
\text { control }\end{array}$ \\
\hline 3 & $\begin{array}{l}\text { July 28, } 2006- \\
\text { Feb. 13, } 2007\end{array}$ & $\begin{array}{l}\text { Changing course } \\
180^{\circ}\end{array}$ & Geography & Abundance/options \\
\hline 4 & $\begin{array}{l}\text { Feb. 14, } 2007 \text { - } \\
\text { May 28, } 2008\end{array}$ & Hitting stride & Accounting & $\begin{array}{l}\text { Empowerment/con } \\
\text { trol }\end{array}$ \\
\hline 5 & $\begin{array}{l}\text { June } 2008 \text { - May } \\
12,2009\end{array}$ & $\begin{array}{l}\text { Stumbling over } \\
\text { hurdles }\end{array}$ & Economy & $\begin{array}{l}\text { Volatility/lack of } \\
\text { control }\end{array}$ \\
\hline 6 & $\begin{array}{l}\text { May 13, } 2009 \text { - } \\
\text { Present }\end{array}$ & Staying the course & All of the above & All of the above \\
\hline
\end{tabular}

\section{Environmental pricing}

In early April 1998 (“Starting line, 1998-2000"), Northwest Environment Watch, now the Sightline Institute, published a booklet titled Tax Shift: How to Help the Economy, Improve the Environment, and Get the Tax Man off Our Backs (Durning and Bauman 1998). The authors set out their task as follows:

... the biggest and least-discussed problem is this: We tax the wrong things. Mostly, we tax things we want more of, such as paychecks and enterprise, not things we want less of, such as pollution and resource depletion. Naturally, we get less money and more messes. Doing the opposite would yield double dividends: cleaner air and flusher bank accounts (Durning and Bauman 1998: 5).

Environmental pricing mechanisms assign a value to the non-human environment for the purpose of reflecting the environment in the market 
system (see: Goodstein 1999, Gowdy and O’Hara 1995, Hardin 1968, Stern 2006). Durning and Bauman frame tax shifting as a means to internalize environmental considerations into decision-making: "in billions of individual choices, the interests of the climate would become a consideration, not through conscious do-goodery but through the persuasiveness of the price tag" (1998: 32).

There are different reactions to such environmental pricing. From a materialist perspective, environmental pricing is a "democracy extended to things": carbon taxation gives the atmosphere a voice in political decision-making (Latour 1993: 12). For some, it represents continuing expansion of capitalist markets, supporting Marx's claim that the "development of the importance of money (... exchange value) leads to the transformation of all human activities into patterns modeled on monetary transactions" (Hartsock 1998: 16).

Using a quasi-materialist approach, Slocum (2004) analyzes the climate campaigns of two organizations: Cities for Climate Protection's emphasis on cost-saving energy efficiency measures and Greenpeace Canada's emphasis on polar bear imagery. Slocum concludes that such symbols act as "lowest common denominators" from which ideas and values are inevitably excluded (2004: 430). For example, a focus on the cost-effectiveness of energy efficient measures treats humans as "passive, ignorant, and responsive to price stimulus rather than as active, knowledgeable people for whom energy has different meanings" (Slocum 2004: 423). Slocum concludes that both humans and non-humans are rendered one dimensional by the use of symbols, eliciting images of Hobbesian "human calculating machines" (Hartsock 1998: 26). Such critiques of environmental campaigns should not outweigh their merits, but do pose a valuable question of how to effectively frame the relationship between the human and non-human environment. Drawing on Latour, Slocum (2004) observes that humans are shaped by their environments and that this needs to be acknowledged in politics.

Advocates of carbon taxation in British Columbia ascribe different weight to environmental considerations. For example, one research participant, in describing the social implications of addressing climate change stated:

... [not] leaving your computer on over night, turning the heat down a little bit, investing in a sweater. All those sorts of things are things that can actually save people money. .... I don't have the list off the top of my head like I used to, but, I mean, there are literally hundreds and hundreds of dollars a year that can be saved if people decide that they want to save them (2009). 
By contrast another research participant stated:

Our job is to have them think about carbon. So, if they want to-, if they are entertaining a rezoning for an industrial park, they need to be thinking about, 'Is transit accessible?' If it isn't transit-accessible, they're just adding to the carbon load of the community (2009).

These two quotes are both from carbon tax supporters. However, the former emphasizes humans as primarily individual economic agents, whereas the latter emphasizes humans as part of a collective ecological system. It is the difference between changing a light bulb and a new way of thinking.

Environmental tax shifting is ambiguous in nature. For some it reflects an ethic of care towards the environment and a critical reorientation of social-ecological relationships. For others it is a means to perpetuate capitalist markets, distilling the complexity of ecoystems through a narrow economic lens. This nebulous nature is played up as an advantage by Durning and Bauman who frame tax shifting as appealing to a broad political base:

Tax shifts pursue liberal ends, such as environmental restoration and a living wage, by conservative means, such as relying on free markets and rewarding enterprise. Tax shifts pursue conservative ends, such as personal freedom and responsibility, by liberal means, such as making the polluter pay (Durning and Bauman 1998: 84).

This broad political appeal is illustrated by the fact that both the New Democratic Party in the 1990s and the Liberal Party in the later-2000s endorsed the concept of environmental tax shifting. Inherent within carbon taxation specifically and environmental pricing initiatives generally is a tension between further subjecting the environment to a growthoriented economic logic and using it as a tool to provoke a rethinking of social-ecological relationships. The design of the tax (e.g. taxation level, absence or presence of exemptions), the nature of complementary policies (e.g. land-use and transport policies) and the larger political ecology (e.g. promotion or phasing out of fossil-fuel based industries) are valuable in assessing whether a carbon tax perpetuates the status quo or marks a shift to a low-carbon or post-carbon society.

\section{The Pine Beetle Epidemic}

Discussion of environmental tax shifting hit a road block in 2001 ("Hitting the wall, 2001-2006"), when the Liberal Party replaced the New 
Democratic Party. The environmental tax shifting pilot projects proposed by the New Democrat Party were sidelined and Premier Gordon Campbell pursued traditional taxation measures. Campbell implemented "bold, 25\% tax cuts on the first day in office [which] sent the clear signal that B.C. was open for business. These tax cuts gave B.C. some of the lowest personal income tax rates in the country" (British Columbia Liberal Party 2009). Of this period, a research participant commented, "I don't think [the Liberal] government paid a lot of attention to climate change up until two years ago [2007]. .... it would be fair to say that-, that there were a lot of people in government who were in denial, politically certainly, about climate change" (2009).

However, while the government marginalized action on climate change the continuous connection between the natural and social orders continued (Latour 1993). The non-human environment continued to shape and be shaped by humans. Indeed, in the context of climate change, the scale of such co-construction is profound. Humans are engaged in a collective, real time climate experiment that is "happening on us, with us, through the action of each of us, on all of us, with all the oceans, the high atmosphere, and even the Gulf Stream" (Latour 2011).

Pine beetles and lodgepole pine trees are species native to the Central Plateau ecosystem of interior British Columbia. However, a variety of factors converged to upset the balance between these two species and propel a pine beetle epidemic of unprecedented scale: pine beetles flourished under changing climatic conditions, forestry practices promoted even-age monocultures, and parks were protected from regenerative fires (Nikiforuk 2011). The beetle population doubled as, due to warmer temperatures, beetles matured within the span of one year, not two (Nikiforuk 2011). In addition, winters which had previously been cold enough to kill the previous year's adult pine beetle population, reaching lows of approximately -35 degrees Celsius, were no longer effective in this capacity (British Columbia Ministry of Forests and Range 2009). Consequently, the scale of a normal beetle infestation was exacerbated in both extent and duration (Nikiforuk 2011).

The number and tenor of press releases is telling. On June 25, 2001, the British Columbia Ministry of Forests and Range issued a press release titled, "Task force to address pine mountain beetle epidemic; 0.5 million hectares affected" (British Columbia Ministry of Forests and Range 2001). On May 26, 2006, the Ministry issued a press release titled: "B.C., Alberta work together to limit beetle spread," in which it is stated that the beetle affects an "area greater than 8.7 million hectares" and where it is estimated that " $80 \%$ of lodgepole pine forests in B.C. will die" (British Columbia Ministry of Forests and Range 2006). As the 
beetle population increased, so did political and public concern. In 2001 the Ministry of Forests and Range issued four press releases related to the pine beetle infestation, while in 2006, 36 press releases were issued. The primary concern related to the pine beetle infestation, as framed in Ministry press releases, was with regard to the forestry sector. Of the 2006 press releases, all but three directly relate to timber management.

According to one research participant, the pine beetle was a source of "tonnes of debate" on climate change in British Columbia (2009). Another research participant reflects:

I think it was 2006, um, it became-, there was a quickening in the world around the issue of climate change. [...] And in British Columbia we have a great example of the damage of climate change in our pine forest; 80 per cent of the pine forest will be dead by 2013. One of the reasons it'll be dead, it's just one, but one of them is that the-, when it was first identified as a problem [...] the solution was to wait for the cold winter to kill it. And the cold winters didn't come for over a decade (2009).

As evidence of the link between the beetle epidemic and climate change mounted, paired with the growing awareness of the related economic burden, the pine beetles and pine trees set the stage for climate action.

In addition to the pine beetle epidemic, British Columbians experienced other events that were of the type expected under changed climatic conditions. A research participant summarizes some of the climate-related events faced by British Columbians, such as the 2006 windstorm that struck Vancouver's Stanley Park, as well as

... people in the farther north dealing with the-, you know, the warmer winters and those effects. We had the ice jams on the Peace [River] and affecting-, um, you know, communities with flooding. So, I think British Columbians were more attuned to the impacts of climate change and saying you know, 'Geez, we may be a small contributor to carbon, but we're going to be bearing some of the cost' (2009).

The collective experiment engaged in by humans with the non-human environment became more apparent. Large scale events startle humans into a realization of their co-constructed relationship with the non-human environment, and in some cases may create windows of opportunity to "navigate social-ecological transitions" (Folke et al. 2010: 20). The experience of the pine beetle epidemic, in combination with other local impacts and a greater cultural consciousness of climate change facilitated the development of a provincial carbon tax. 


\section{Political Economy Of Place}

On July 28, 2006 (“Changing course $180^{\circ}$, July 28, 2006-February 13, 2007"), the Crown Corporation, B.C. Hydro, awarded contracts for new electricity generation capacity. A research participant describes the situation,

... B.C. Hydro, um, signed electricity purchase agreements with two, um, projects that were going to build coal-fired plants in B.C.; one in Tumbler Ridge and one in-, near Princeton, I think. Um, the first two coal-fired plants in British Columbia and we were going to start building them in 2008/2009. It's like, 'You've got to be joking!' .... All you have to do is just tell people, and even people who weren't sympathetic to environmental issues, they would stop ... and they'd go 'We are?' 'We are!' [indicating disapproval] (2009).

This participant's comment suggests that the threshold of activities deemed acceptable in British Columbia's energy sector is determined in part by its political economy. British Columbia, in contrast to provinces such as Alberta, Nova Scotia and Saskatchewan derives its power from hydroelectricity. The basic amenities of heat and light do not rely on fossil fuel consumption. British Columbia's "political economy of place," notably its hydroelectricity resources and its pine beetle-plagued forestry industry, may have played a role in the implementation of a carbon tax (Fisher 2006: 472).

Fisher (2006), in an examination of the spatial distribution of coal deposits and high employment levels in the coal industry, finds that resource base, not political affiliation, is the key factor in influencing voting patterns on climate change bills. Both Democratic and Republican representatives of coal-rich states vote against climate change bills, as such policy measures are perceived to be a direct threat to livelihoods (Fisher 2006). Fisher posits that less expensive renewable energy technology or clean coal technology may result in changing voting practices (2006: 488). It could be argued that British Columbia, as a jurisdiction that is less economically reliant on greenhouse gas emissions, is predisposed to become even less so. Notably, Quebec, another province rich in hydroelectricity, passed a revenue-generating carbon tax, albeit set at the flat, nominal level of $\$ 10$ per tonne.

\section{Ghg Accounting}

Within six months of announcing plans for coal-fired power plants, and influenced by Governor Schwarzenegger's well-received Global Warm- 
ing Solutions Act, the government of British Columbia was taking concerted action on the issue of climate change ("Hitting stride, February 14, 2007-May 28, 2008"). The 2008 Climate Change Action Plan committed the province to decreasing greenhouse gas emissions 33 per cent by 2020; the carbon tax was one of a suite of measures aimed at achieving this target.

An underlying component of British Columbia's greenhouse gas emission reduction target generally and carbon taxation policy specifically was making carbon emissions visible. A system of measurement, such as detailed by MacKenzie (2009) in his description of the European Union Emissions Trading Scheme, is one means to recognize the role of the non-human in constituting the social (Latour 1993). MacKenzie (2009) uses a materialist perspective to trace the emergence of the European Union Emissions Trading Scheme. He notes that "rather than building a new system of metrology...the European scheme as far as possible measures $\mathrm{CO}_{2}$ emissions by re-employing the existing meters used to measure energy input" (MacKenzie 2009: 158). However, a system of national greenhouse gas emissions databases had to be developed to account for ongoing carbon market transactions.

Similarly, British Columbia developed an approach for tracking greenhouse gas emissions across all sectors and encountered the challenge of translating pollution into a figure that could be used by humans to monitor societal emission levels. The first level of decision-making was with regard to what pollutants and emission sources should be accounted for. One research participant recalls that "the area that we worked most closely on after the policy decisions were made was around how do you measure carbon emissions, what should be in, what should be out" (2009). A second, more technical level of decision-making involved identifying pollution volumes and emissions factors, as well as estimating projected carbon tax revenues based on these figures. One research participant recalls the experience,

...so you could look at the transportation sector, you could look at, uh, residential housing, commercial, how much is being used, some of that was fairly easy to get at, you could get, for example, the amount of natural gas that was being consumed. That-, you knew that, and you multiplied that by an emissions factor and away you went. But in the upstream oil and gas sector, some of that is known, some of it is not known, so that was more difficult. I think there was also a certain-, um, um, industrial sectors were-, it's not that terribly well-known as to what the emissions factor is. So that ... was probably more controversial, just among us, when we were developing that (2009). 
This inventory is maintained and published annually, and is used to determine the success of the province's efforts to meet its emissions reduction targets. In addition, all public services, such as municipalities, schools and hospitals, were required to become carbon neutral by 2010 (Government of British Columbia 2009b). To this end, municipalities had to measure, reduce, offset and report their greenhouse gas emissions to provincial authorities (Government of British Columbia 2009b). Greenhouse gas emissions in British Columbia municipalities changed from being invisible and untracked to visible and closely monitored (Rutland and Aylett 2008). It is on the basis of such "concrete, precise, and measured knowledge" that the government of British Columbia can govern greenhouse gas emissions (Foucault 1988: 151). Notably, however, the carbon tax belies the challenge of translating invisible gases into dollar figures.

Statistics are a means of knowing and understanding who and what is governed. Part of the role of the state is "the evaluation of the relationship between resources and its inhabitants, the constructing of tables analyzing wealth and its circulation" (Foucault 1988: 140). Climate change is a signal that atmospheric carbon emission concentrations are too high, and therefore humans need to reduce emissions. In response, the complex global carbon cycle is reduced into greenhouse gas emissions measurements. ANT highlights how the government aims to make greenhouse gas emissions, previously invisible both figuratively and literally, visible. The government aims to inscribe a uniform "legibility" on a dynamic ecosystem and diverse emission sources (Scott 1998: 2).

Shaw (2011) finds such a focus on greenhouse gas emission reduction in British Columbia too narrow, arguing that a broader, more holistic energy lens would better protect the environment. For example, a focus on greenhouse gas emissions reduction in British Columbia encourages the development run-of-river hydroelectricity projects, but does not address issues such as energy intermittency, cumulative effects or the "enclosure of public resources for private gain" inherent in such projects (Shaw 2011: 752). These concerns echo Slocum's (2004) critique that a focus on lowest common denominators fails to achieve a reorientation of social-ecological dynamics.

\section{Eмотіоn}

Like greenhouse gas emission metrology, the emotion expressed by stakeholders may also be a gauge of the degree to which the co-constructed nature of the human and non-human environment is perceived 
and valued. The expression of emotion on the part of professionals who are directly and indirectly involved in policy development is generally uncommon, therefore references to emotion by research participants, upon recounting the carbon taxation policy development process, were notable.

For example, the reading of the 2008 Budget in which the date of the carbon tax implementation is announced, was cause for celebration. One research participant recalls that "there were a number of us that were in the House and that was kind of a key day." Another research participant reflects,

... I went and sat in the Legislature for that one [. . . Y You know, that was, kind of, the high point of my career, frankly, was to see that come into place. I'll be honest, the day after I found out it was actually going to happen it was like, 'I could go do something else now [. . . ] [I never thought] that kind of thing was actually going to happen. So it was pretty remarkable [laughter].

Similarly, another research participant reflects,

... I mean, I had no idea that they would do it. I mean, I'm not privy to the decision-making, so I was listening to the Budget in 2008 and I was-, you know, like 'They did it, they did it.' That was-, and the emails flooded in from all over: "They did it!" So, I mean it was a pretty exciting-, I tell you it was one of the more exciting times. Shows how geeky we are [laughter].

Another research participant recalls,

I almost cried giving media during the Budget lock-up, I was so happy. I was having to fight back tears: 'Yes, there's all this nasty stuff [that's not environmentally sustainable in the Budget], but there's a carbon tax' [laughter].

The proximate source of the research participants' elation is the fact that an environmental pricing measure, specifically a textbook carbon tax, was implemented. However, another source of excitement may be the fact that environmental pricing represents a change in the nature of the relationship between the human and non-human environment, though whether this is in the form of a reformed capitalism or a step toward a transformed social-ecological relationship likely varies from person to person. British Columbia's carbon tax, while an incremental backstop measure, shifts the environment from a peripheral after thought to a core consideration. The emotional commitment of such individuals may have been influential in the fifth phase, "Stumbling over hurdles, June 2008May 12, 2009" when political and public resistance to the tax spiked. 
Similarly, such commitment may be key in the sixth and current phase, "Staying the course, May 13, 2009 - Present" should formal challenges to the tax be forwarded.

\section{Discussion}

This paper explores five areas in the development of British Columbia's carbon tax where the non-human environment was directly or indirectly made a more central consideration in policy development: environmental pricing, the pine beetle epidemic, political economy of place, greenhouse gas accounting and emotion. The carbon taxation policy development process was not simply a case of humans acting on a passive, peripheral non-human environment, but instead illustrates a response to more complex intersections of the political and the ecological (Latour 1993). ANT, with its emphasis on the co-construction of human and non-humans, is useful in describing and problematizing the way humans relate to the non-human environment.

Environmental pricing and greenhouse gas accounting aim to incorporate environmental considerations into human accounting schemes, to quantify complex ecosystems in the spirit of "what gets measured gets managed." Both are efforts to increase the legibility of the nonhuman environment in a human vernacular that to some perpetuates the capitalist status quo, and for others incrementally reins in capitalism. In the case of the latter, some humans are not only intellectually, but also emotionally, committed to the more holistic accounting represented by environmental pricing as evidenced by the strong response of individuals involved directly and indirectly in British Columbia's carbon tax development. Carbon pricing is viewed by some as a prerequisite for balancing the relationship between humans and the atmosphere.

The tracks left by pine beetles in tree trunks and the swaths of dead pine forest can arguably be construed as an ecological vernacular, a legibility imposed by the non-human environment on humans. British Columbia's landscape, and in turn its political ecology, has been rewritten by the pine beetle population which was itself rewritten by a changing climate caused by anthropogenic emissions. Such an extreme event lays bare not only the tenacious and tenuous nature of the human relationship with the non-human environment, but reveals the artificiality of the human/non-human dichotomy. Just as bacteria populate an elbow crook, humans populate an ecosystem. Notions of scale and hierarchy are easily disrupted. The events over the course of a decade that led to the development British Columbia's carbon tax illustrate the inseparability of humans and non-humans, that is, the indivisibility of the planetary 
ecosystem, lending support to Bennett's vital materiality. Human actions on the environment have a boomerang effect where the "risks of modernization sooner or later also strike those who produce or profit from them" (Beck 1992: 23).

But though this is increasingly apparent, is not necessarily embraced. Humans resist enrollment in environmental assemblages, such as illustrated by Campbell's marginalization of the climate change portfolio upon election in 2001, preoccupation with the economic implications of the pine beetle epidemic between 2001 and 2006, and the New Democratic Party's politically-motivated "Axe the Tax" campaign in 2009. A Latourian lens highlights the interdependence of the human and non-human environment, and the simultaneous human resistance to such interdependence. Bennett's analogy of the environment to "unruly relatives" reflects such a resistance:

Admit that humans have crawled or secreted themselves into every corner of the environment; admit that the environment is actually inside human bodies and minds, and then proceed politically, technologically, scientifically, in everyday life, with careful forbearance, as you might with unruly relatives to whom you are inextricably bound and with whom you will engage over a lifetime, like it or not (emphasis added) (Bennett 2010: 116).

A societal shift in an attitude from reluctant forbearance to a willing embrace is intuitively a logical prerequisite for achieving environmental sustainability. In this article the focus is on the ecological emphasis of ANT in order to tease apart the co-construction of human and non-human nature in the policy development process. With climate change, the co-constructed networks of human and non-humans "come out of hiding" (Latour 1993: 139). Greenhouse gases, pine beetles and humans are engaged in a real-time climate experiment where ecological and policy reactions are entwined (Latour 2011). British Columbia's carbon tax, which aims to make the atmosphere visible in market transactions, is an attempt to balance the human relationship with the non-human environment. The use of a post-humanist paradigm such as ANT serves to highlight the interdependence of the human and non-human environment, and the simultaneous human resistance to such interdependence.

British Columbia's carbon tax may be one barometer of the quality of human relationship with the environment. Upholding the tax may, in the face of obstacles, be an indication that British Columbian citizens and decision-makers recognize that "we can no longer be human in the same way" (Latour 1993: 142) and a commitment to an adroit, or at least a more adroit dance, with the non-human environment (Murphy 2004: 254). A continuation of the annual price escalator component of the car- 
bon tax, complemented by protections for low-income earners, would be an even stronger indication.

\section{REFERENCES}

Ascui, Francisco and Heather Lovell. 2011. As frames collide: Making sense of carbon accounting. Accounting, Auditing and Accountability Journal 24 (8): 978-999.

Beck, Ulrich. 1992. The Risk Society: Toward a New Modernity. London: Sage.

Besel, Richard. 2011. Opening the "black box" of climate change science: ActorNetwork theory and rhetorical practice in scientific controversies. Southern Communication Journal 76 (2): 120-136.

Bennett, Jane. 2010. Vibrant Matter: A Political Ecology of Things. Durham: Duke University Press.

Blok, Anders. 2011. Clash of the eco-sciences: Carbon marketization, environmental NGOs and performativity as politics. Economy and Society 40 (3): 451-476.

British Columbia Climate Action Team. 2008. Meeting British Columbia's Target: A Report from the B.C. Climate Action Team. http: //www.bcsea.org/ sites/default/files/Climate_Action_Team_Final_Report.pdf Access date: September 25, 2015.

British Columbia Ministry of Forests and Range. 2009. Mountain pine beetle facts.https: //www.for.gov.bc.ca/hfp/mountain pine beetle/UpdatedBeetle-Facts_May2012.pdf. Access date: September 25, 2015.

British Columbia Ministry of Forests and Range. 2006. B.C., Alberta work together to limit beetle spread. Press release. May 26, 2006. http: //www2. news.gov.bc.ca/news_releases 2005-2009/2006FOR0048-000679.htm Access date: September 25, 2015.

British Columbia Ministry of Forests and Range. 2001. Mountain Pine Beetle in B.C. http: //www.bcliberals.com/EN/premier/premier_first_term_2001__2005/ Access date: September 25, 2015.

Callon, Michael. 1986. Some Elements of a Sociology of Translation: Domestication of the Scallops and the Fishermen of St Brieuc Bay. In Power, Action and Belief: A New Sociology of Knowledge, edited by John Law. London: Routledge and Kegan Paul.

Descheneau, Phillipe. 2012. The currencies of carbon: Carbon money and its social meaning. Environmental Politics 21 (4): 604-620.

Duff, David. 2008. Carbon taxation in British Columbia. Vermont Journal of Environmental Law 10 (1): 85-105.

Durning, Alan and Yorum Bauman. 1998. Tax Shift: How to Help the Economy, Improve the Environment, and Get the Tax Man off Our Backs. NEW Report No.7. Seattle: Northwest Environment Watch. 
Fisher, Dana. 2006. Bringing the material back in: Understanding the U.S. position on climate change. Sociological Forum 21 (3): 467-494.

Folke, Carl, Stephen Carpenter, Brian Walker, Marten Scheffer, Terry Chapin, Johan Rockström. 2010. Resilience thinking: Integrating resilience, adaptability and transformability. Ecology and Society 15 (4) : 20-28.

Foucault, Michel. 1988. Technologies of the Self: A Seminar with Michel Foucault, edited by L. Martin, H. Gutman and P. Hutton. Amherst: University of Massachusetts Press.

Goodstein, Eban. 1999. Economics and the Environment. New Jersey: Prentice Hall.

Government of British Columbia. 2009a. Tax cuts, funded by a revenue neutral carbon tax. http: //www.fin.gov.bc.ca/tbs/tp/climate/A2.htm. Access date: September 25, 2015

Government of British Columbia. 2008a. Budget Speech: Turning to the Future, Meeting the Challenge. http: //www.bcbudget.gov.bc.ca/2008/speech/ Access date: September 25, 2015.

Government of British Columbia. 2008b. Climate Action Plan. http: //www. toolkit.bc.ca/Resource/Making-Progress-BC's-Climate-Action-Plan Access date: September 25, 2015.

Government of British Columbia. 2008c. Budget 2008 and BC's Climate Action Dividend. http: //www.bcbudget.gov.bc.ca/2008/backgrounders/backgrounder_carbon_tax.htm Access date: September 25, 2015.

Government of British Columbia. 2007. Speech from the Throne. 2007 Legislative Session: 3rd Session, 38th Parliament. February 13, 2007.

http: //www.leg.bc.ca/38th3rd/4-8-38-3.htm Access date: September 25, 2015.

Gowdy, John. and Sabine O'Hara. 1995. Economic Theory for Environmentalists. New York: St. Lucie Press.

Hardin, Garrett. 1968. The tragedy of the commons. Science 168 (13): 12431248.

Harvey, D. 2010. A Companion to Marx's Capital. London: Verso.

Hocking, Morgan and John Reynolds. 2012. Nitrogen uptake by plants subsidized by Pacific salmon carcasses: a hierarchical experiment. Canadian Journal of Forest Research 42: 908-917.

Hsu, Shi-Ling, Joshua Walters, and Anthony Purgas. 2008. Pollution tax heuristics: An empirical study of willingness to pay higher gasoline taxes. Energy Policy 36 (9): 3612-3619.

Hursh, David and Joseph Henderson. 2011. Contesting global neoliberalism and creating alternative futures. Discourse 32 (2): 171-185.

Intergovernmental Panel on Climate Change. 2014. Climate Change 2014: Mitigation of Climate Change. Summary for Policy Makers. Geneva: IPCC. 
Latour, Bruno. 2011. From multiculturalism to multinaturalism: What rules of method for the new socioscientific experiments? Nature and Culture 6 (1): $1-17$.

Latour, Bruno. 2005. Reassembling the Social: An Introduction to Actor-Network-Theory. Oxford: Oxford University Press.

Latour, Bruno. 1996. Aramis, or the Love of Technology. Cambridge: Harvard University Press.

Latour, Bruno. 1993. We Have Never Been Modern. Cambridge: Harvard University Press.

MacKenzie, Donald. 2009. Material Markets: How Economic Agents are Constructed. Oxford: Oxford University Press.

McMenamin, Mark and Diana McMenamin. 1994. Hypersea: Life on Land. New York: Columbia University Press.

Mills, Charles Wright. 1956. The Power Elite. Oxford: Oxford University Press.

Murdoch, Jonathon. 2001. Ecologising the social: Actor-Network Theory, coconstruction and the problem of human exemptionalism. Sociology 35 (1): 111-133.

Nikiforuk, Andrew. 2011. Empire of the Beetle: How Human Folly and a Tiny Bug are Killing North America's Great Forests. Vancouver: D \& M Publishers Inc.

Peet, Chelsea and Kathryn Harrison. 2012. Historical legacies and policy reform: Diverse regional reactions to British Columbia's carbon tax. BC Studies 173: 97-122.

Pembina Institute and Simon Fraser University. 2012. British Columbia's Carbon Tax: Exploring Perspectives and Seeking Common Ground. http: // www.pembina.org/pub/2352 Access date: September 25, 2015.

Pyne, Stephen. 2009. The human geography of fire: A research agenda. Progress in Human Geography 33 (4): 443-446.

Rutland, Ted and Alex Aylett. 2008. The work of policy: Actor networks, governmentality, and local action on climate change in Portland, Oregon. Environment and Planning D: Society and Space 26: 627-646.

Schnaiberg, Allan and Kenneth Gould. 2000. Environment and Society: The Enduring Conflict. Caldwell, New Jersey: The Blackburn Press.

Scott, James. 1998. Seeing like a state: how certain schemes to improve the human condition have failed. New Haven: Yale University Press.

Slocum, Rachel. 2004. Polar bears and energy-efficient light bulbs: strategies to bring climate change home. Environment and Planning D: Society and Space 22: 413-438.

Sodero, Stephanie. 2011. Policy in motion: Reassembling carbon pricing policy development in the Personal transport sector in British Columbia. Journal of Transport Geography 19 (6): 1474-1481. 
Sodero, Stephanie. 2010. Policy in motion: Reassembling carbon pricing policy development in the Personal transport sector in British Columbia. MSc Dissertation. Oxford: University of Oxford.

Stern, Nicholas. 2006. Stern Review on the Economics of Climate Change. http: //www.wwf.se/source.php/1169157/Stern\%20Report_Exec\%20Summary.pdf Access date: September 25, 2015

Sustainable Prosperity. 2012. British Columbia's Carbon Tax Shift: The First Four Years. http://www.sustainableprosperity.ca/sites/default/files/ publications/files/Read $\% 20$ Report $\% 20$ here $\% 20 \% 20$ British $\% 20$ Columbias $\% 20$ Carbon $\% 20$ Tax $\% 20$ Shift $\% 20$ The $\% 20$ First $\% 20$ Four $\% 20$ Years. pdf Access date: September 25, 2015.

The Tyee. 2013. BC Liberals' 12 Years of Tax Shifts, Explained. http://thetyee. ca/News/2013/05/06/BC-Liberals-Tax-Shifts/ Access date: September $25,2015$.

Tversky, Amos and Daniel Kahneman. 1981. The framing of decisions and the psychology of choice. Science 211 (4481): 453-458.

Urry, John. 2008. Climate change, travel and complex futures. British Journal of Sociology 59 (2): 261-279.

Wübbeke, Jost, 2013. The science-politics of climate change in China: Development, equity, and responsibility. Nature and Culture 8 (1): 8-29.

\section{ACKnOWLedgements}

Thank you to Dr. Mark C.J. Stoddart, Petra Hroch, and three anonymous reviewers for their insightful comments. I would like to acknowledge the guidance of Dr. Tim Schwanen, and the financial support of the Canadian Transportation Research Forum. And, in the spirit of Actor-Network Theory, I would like to recognize the morale boost provided by a footnote in Latour's Reassembling the Social that led me to the website Paris ville invisible, after which things started to make sense.

Stephanie Sodero is a doctoral candidate in Sociology at Memorial University and a Visiting Scholar at New York University's Superstorm Research Lab. Her research interests include mobility, social-ecological resilience and climate policy. Her $\mathrm{PhD}$ research project, Navigating disruption: Mobile society and Hurricanes Juan and Igor, focuses on the impact of severe weather events on transport systems. She has published in Mobilities, Journal of Transport Geography and Environmental Sociology.

sbs105@mun.ca 